\title{
The RNase III Family: A Conserved Structure and Expanding Functions in Eukaryotic dsRNA Metabolism
}

Bruno Lamontagne, Stéphanie Larose, Jim Boulanger, and Sherif Abou Elela*

Département de Microbiologie et d'Infectiologie, Faculté de Médecine, Université de Sherbrooke, Sherbrooke, Québec, Canada J1H 5N4

\begin{abstract}
The last few years have witnessed the appreciation of dsRNA as a regulator of gene expression, a potential antiviral agent, and a tumor suppressor. However, in spite of these clear effects on the cell function, the mechanism that controls dsRNA maturation and stability remains unknown. Recently, the discovery of eukaryotic orthologues of the bacterial dsRNA specific ribonuclease III (RNase III) suggested a central role for these enzymes in the regulation of dsRNA and eukaryotic RNA metabolism in general. This article reviews the structure-function features of the eukaryotic RNase III family and their roles in dsRNA metabolism with an emphasis on the yeast RNase III. Yeast RNase III is involved in the maturation of the majority of snRNAs, snoRNAs, and rRNA. In addition, perturbation of the expression level of yeast RNase III alters meiosis and causes sterility. These basic functions of the yeast RNase III appear to be widely conserved which makes it a good model to understand the importance of eukaryotic dsRNA metabolism.
\end{abstract}

\section{The RNase III Family: A Confusion or Ordered} Evolution?

The RNase III family include dsRNA specific ribonucleases that share loosely conserved structural and functional features (Figure 1). Members of the RNase III family are found in all species tested with the exception of archaebacteria where the functions of RNase III are carriedout by the bulge-helix-bulge nuclease (BHB) (LykkeAndersen et al., 1997). Membership in this family requires homology with the structural elements of the founding member, Escherichia coli RNase III (Court, 1993; Nicholson, 1999; Nicholson, 1996). These structural elements include a nuclease domain that exhibits a conserved signature motif and a dsRNA binding domain (dsRBD) that includes a motif specific to the dsRNA binding protein family (Kharrat et al., 1995; St Johnston et al., 1992). Based on structural and evolutionary differences, the RNase III family could be divided into two major subfamilies, the bacterial RNase III family and the eukaryotic RNase III

*For correspondence. Email sabou @courrier.usherb.ca;

Tel. (819) 564-5275; Fax. (819) 564-5392. family (Figure 1). In bacteria, RNase III exists in one form characterized by a classical RNA binding domain and a nuclease domain (Nicholson, 1999). In contrast, eukaryotic RNase III exists in three isoforms that share the basic dsRBD but differ in the number of nuclease domains and in the composition of the $\mathrm{N}$-terminal domain (Filippov et al., 2000; Jacobsen et al., 1999; Lamontagne et al., 2000). The first form contains three domains; the dsRBD, the nuclease domain, and an additional uniquely eukaryotic $\mathrm{N}$-terminal domain required for correct protein conformation and efficient RNA cleavage (Lamontagne et al., 2000). The second form exhibits in addition to these three domains a second nuclease motif at the protein $\mathrm{N}$-terminus $(\mathrm{Wu}$ et al., 2000). Finally, the third form of eukaryotic RNase III contains in addition to the three main eukaryotic domains a fourth distinct helicase domain (Jacobsen et al., 1999; Rotondo and Frendewey, 1996). These obvious variations in the structure of the eukaryotic members of the RNase III family may appear as a product of random evolution independent of the specific needs of the host organism. However, as discussed in this review, recent comparative and functional studies of the different RNase III isoforms suggest an evolutionary pathway that adapts RNase III functions to its eukaryotic environment.

\section{Rnt1p and RNA Processing in Yeasts}

In yeast, four RNase III orthologues have been identified including Rnt1p from Saccharomyces cerevisiae (Abou Elela et al., 1996), Pac1 and Pac8 from Schizosaccharomyces pombe (Rotondo and Frendewey, 1996), and KLRNase III from Kluyveromyces lactis (OzierKalogeropoulos et al., 1998). Rnt1p, Pac1 and KLRNase III belong to the classical RNase III family while Pac8 belongs to the helicase RNase III family. The enzymatic activities of Rnt1p and Pac1 were verified experimentally and were shown to affect pre-rRNA processing in vivo (Abou Elela et al., 1996; Kufel et al., 1999; Nagel and Ares, 2000; Rotondo et al., 1997; Zhou et al., 1999). In contrast, the in vivo existence and functions of both Pac8 and KLRNase III remain to be tested. Pac1 is the first eukaryotic orthologue to be identified based on sequence homology with the RNase III signature motif (lino et al., 1991; Xu et al., 1990). It was isolated as an essential gene that suppresses uncontrolled meiosis (lino et al., 1991; Xu et al., 1990), and suppresses a defect in snRNA metabolism (Rotondo et al., 1995). In addition, overexpression of PAC1 strongly inhibits sporulation in $S$. pombe. Recently, a temperature sensitive allele of $P A C 1$ was isolated and used to demonstrate its role in the processing of U2 snRNA and pre-rRNA 3' ends (Zhou et al., 1999). Unprocessed U2 snRNA and pre-rRNA accumulate upon the inactivation of Pac1 in vivo. In vitro, purified recombinant Pac1 cleaves model substrates of both U2 and 25S rRNA 3' ends generating a product that is a few nucleotides longer than 


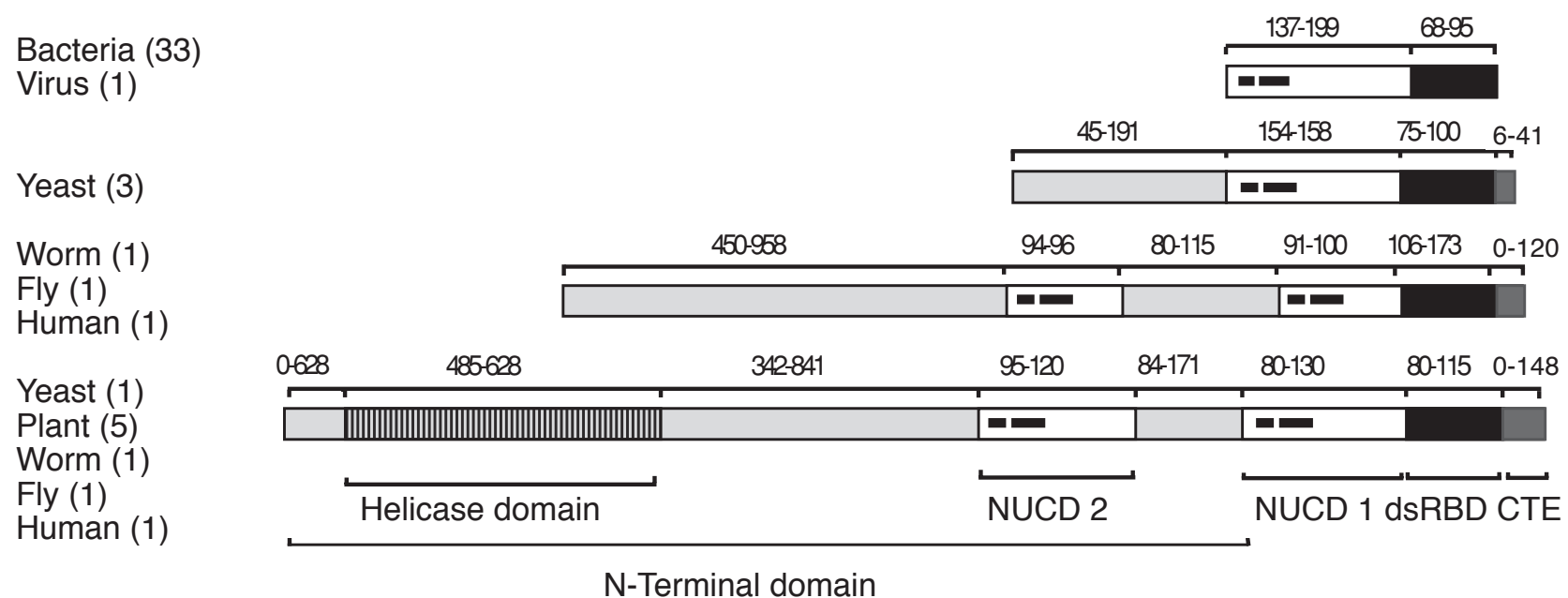

Figure 1. Schematic representation of the RNase III family. Black boxes represent the dsRNA binding domain (dsRBD), dark gray boxes represent the amino acid residues that extend beyond the dsRBD (CTE), white boxes represent the nuclease domain (NUCD), the striped box represent the ATP-dependent helicase domain, light gray boxes represent areas with no known homologies nor predicted functions, and the black lines represent the position of the highly conserved acidic nucleic acid stretches including the RNase III signature sequences. The size range of every domain is indicated in amino acids on top.

the mature form (Rotondo et al., 1997; Zhou et al., 1999). This product is believed to be trimmed by exonucleases to the mature site in vivo (Zhou et al., 1999). The relationship between the RNase III activity of Pac1 and the suppressor phenotype or the effect on sporulation is unclear, but the effects seem unlikely to be mediated through pre-rRNA processing. Unlike Pac1, the S. cerevisiae enzyme is not essential. However, deletion of Rnt1p alters the processing of pre-rRNA, snRNAs, and snoRNAs and results in severe growth defects (Abou Elela and Ares, 1998; Abou Elela et al., 1996; Chanfreau et al., 1998a; Kufel et al., 1999). Cells that lack Rnt1p are temperature sensitive capable of growing only at $26^{\circ} \mathrm{C}$ but not at temperatures higher than $30^{\circ} \mathrm{C}$ (Abou Elela and Ares, 1998; Lamontagne et al., 2000). These multiple severe effects of RNT1 deletion suggest an important role in RNA maturation and possibly RNA decay as well. The following section discusses in detail the biochemical and functional properties of Rnt $1 p$ and its impact on yeast RNA metabolism.

\section{Rnt1p Structure}

S. cerevisiae Rnt1p is transcribed from a single gene located downstream of the spliceosome associated CUS1 gene on chromosome XIII (Abou Elela et al., 1996). Rnt1p has a predicted sequence of 471 a.a with an estimated molecular weight of $54.5 \mathrm{kDa}$ and calculated pl of 8,73 (Lamontagne et al., 2000). The canonical dsRBD motif is located at the C-terminus (positions 372-440) with 25\% identity to the bacterial RNase III and $31 \%$ identity to fission yeast Pac1 (Figure 1 and Rotondo and Frendewey, 1996). However, unlike RNase III and Pac1 dsRBDs, Rnt1p has a highly basic 33 a.a. extension at the $\mathrm{C}$-terminus (Figure 1). The Rnt1p 154 a.a. nuclease domain is similar in size to that of RNase III and Pac1 sharing the same charged amino acid clusters (Lamontagne et al., 2000; Mian, 1997).

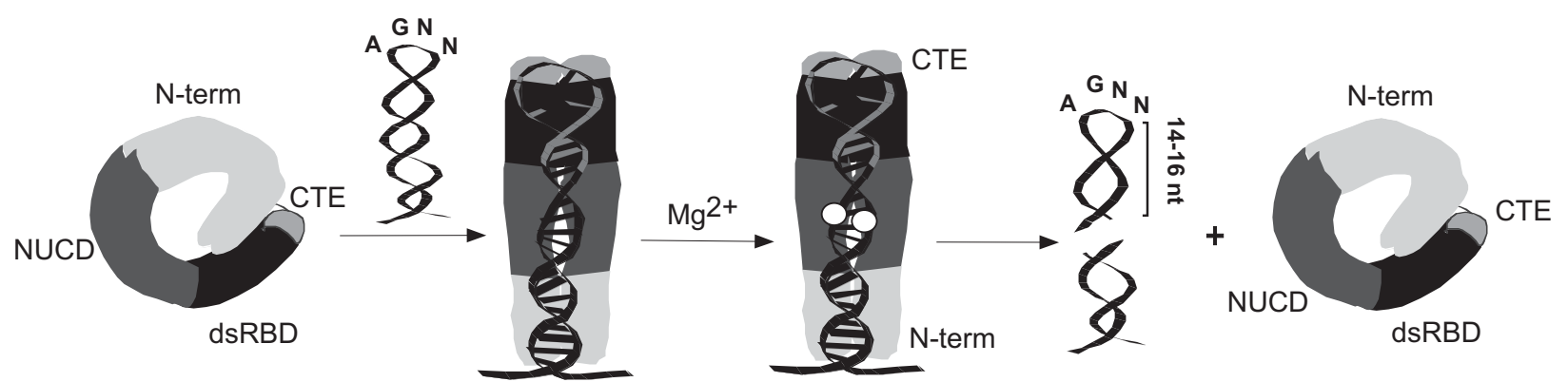

Figure 2. Model for the mechanism of dsRNA cleavage by Rnt1p. Rnt1p forms $108 \mathrm{kDa}$ homodimer through the self-interaction of both dsRBD and N-terminal domain. The homodimer sponsors an intramolecular interaction through its N-terminal and C-terminal domains when inactive. In the presence of an RNA substrate that contains the conserved AGNN tetraloop, the intramolecular interaction is disrupted allowing an interaction between the dsRBD and the RNA. Once the RNA is bound the protein adopts a conformation stabilized by the N-terminal domain self-interaction allowing the positioning of the nuclease domain close to the cleavage site about 14-16 nucleotides from the tetraloop. The cleavage reaction proceeds once the $\mathrm{Mg}^{2+}$ binds to the enzyme presumably through an interaction with the conserved acidic amino acid residues in the nuclease domain (Lamontagne et al., 2000). 
It is likely that these stretches of acidic amino acids in Rnt1p binds divalent metal ions and directs RNA cleavage as suggested for the bacterial RNase III. In addition, Rnt1p possesses the characteristic eukaryotic $\mathrm{N}$-terminal domain that spans 191 a.a. The $\mathrm{N}$-terminal extension has neither an apparent functional motif nor significant homology to Pac1 N-terminal domain (Lamontagne et al., 2000). To determine the contribution of the various domains to Rnt1p function, the different domains were expressed individually and tested for function in vivo and in vitro (Lamontagne et al., 2000; Nagel and Ares, 2000). The dsRBD was shown to be required and sufficient for binding, while the nuclease domain is required for cleavage (Lamontagne et al., 2000; Nagel and Ares, 2000). On the other hand, the N-terminal domain was shown to play an auxiliary role ensuring efficient RNA cleavage (Lamontagne et al., 2000). Deletion of the N-terminal domain reduces the processing of the $25 \mathrm{~S}$ rRNA 3 ' end by about $30 \%$ in vivo and slows growth by $35 \%-40 \%$. Biochemical and genetic assays suggest that the N-terminal domain influences Rnt1p function by mediating both inter- and intramolecular interactions (Lamontagne et al., 2000). Since the N-terminal domain is unique for the eukaryotic members of the RNase III family, it may also serve in vivo as a nuclear localization signal.

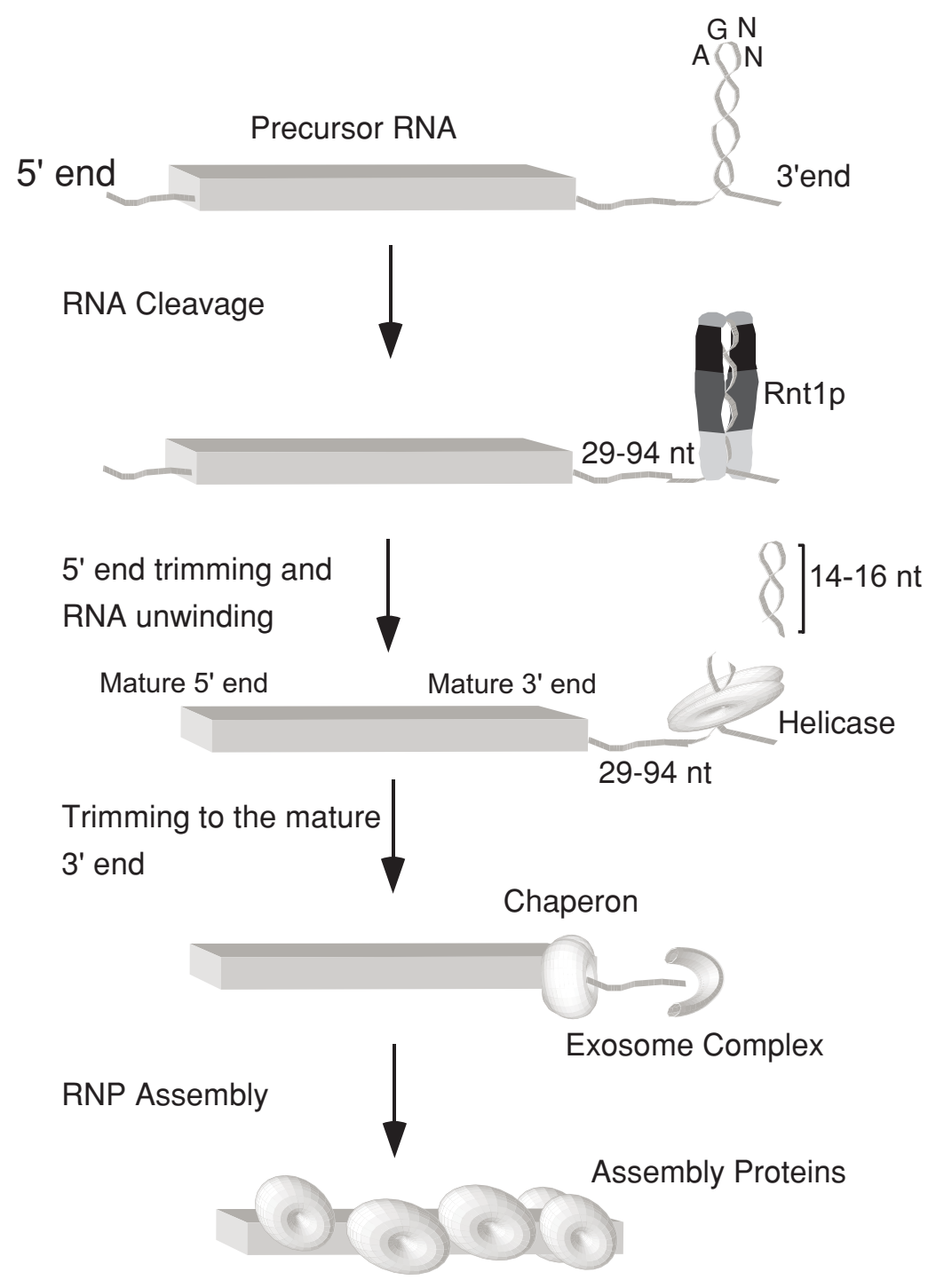

Mature RNP

Figure 3. A general model for in vivo Rnt1p dependent RNA processing pathway. The gray box represents the mature RNA sequence and the lines represent the $5^{\prime}$ and $3^{\prime}$ end nascent extensions. Soon after RNA transcription, Rnt1p binds its cleavage site, cleaves the RNA, and initiates the downstream processing and modification machinery. Rnt1p cleavage site is normally 29-94 nucleotides away from the end of the mature RNA. After Rnt1p cleavage, a helicase activity is required to unwind the lower RNA helix resulting from cleavage reaction. Once unfolded, the RNA is trimmed by exonculeases (e.g. the exosome complex) up to the mature end which is specified by a chaperon or assembly protein (e.g. Lhp1p). The chaperon is normally replaced during the assembly of the mature RNP particles by members of the RNP complex (Allmang et al., 1999; Kufel et al., 2000; van Hoof et al., 2000; van Hoof et al., 2000). 
Expression of Rnt1p mutants that lack the $\mathrm{N}$-terminal domain does not complement RNT1 deletion (Nagel and Ares, 2000). However, similar N-terminal deletion expressed in fusion with nuclear localization signal or from strong promoters support cellular growth albeit less efficiently than wild type enzymes (Lamontagne et al., 2000). Deletion of S. pombe Pac1 N-terminal domain inhibits RNA cleavage in crude extracts suggesting a similar role in RNA cleavage (lino et al., 1991). It is tempting to suggest that, despite the lack of sequence conservation, the basic functions of the $\mathrm{N}$-terminal domain are preserved among eukaryotic RNase III.

\section{Rnt1p Substrate}

Comparison of Rnt1p natural substrates (Abou Elela and Ares, 1998; Chanfreau et al., 2000; Nagel and Ares, 2000) reveals the presence of a terminal tetraloop 14 to $16 \mathrm{bp}$ from the cleavage site with the conserved sequence AGNN (Figures 2 and 3). Deletion of this sequence abolishes cleavage while deletion of sequences close to the cleavage site does not affect the substrate recognition or cleavage (Abou Elela and Ares, 1998; Chanfreau et al., 2000; Nagel and Ares, 2000). Mutations that change the tetraloop conserved AGNN sequence to GUNN slow RNA cleavage in low monovalent salt concentrations and block it in concentrations higher than $100 \mathrm{mM}$ (Nagel and Ares, 2000). Changing the tetraloop sequence to GANN or GAAA also slows cleavage indicating that the AG sequence plays an important role in substrate recognition (Chanfreau et al., 2000). Indeed, gel mobility shift assays demonstrate that the dsRBD of Rnt1p which contains the 74 a.a. canonical RNA binding motif and an additional non-conserved 54 a.a. is capable of recognizing the AGNN tetraloop (Nagel and Ares, 2000). These experiments prompted the surprising conclusion that Rnt $1 p$ uses the apparently single stranded tetraloop to determine the cleavage site. On the other hand, Rnt1p may not recognize the AGNN sequence itself but instead it may recognize a particular structure that forms through that sequence and the adjacent RNA helix. It is also unclear whether the canonical dsRNA binding motif itself recognizes the tetraloop or this particular recognition is derived by the adjacent non-conserved amino acid within the C-terminus of Rnt1p (Lamontagne et al., 2000; Nagel and Ares, 2000). A role for the non-conserved amino acids in the recognition of the tetraloop would explain the inability of Pac1 and RNase III to recognize the tetraloop (Nicholson, 1999; Rotondo et al., 1997). In addition to its proposed role as a substrate identity element, the tetraloop appears to assist in determining the site of cleavage. It was shown that Rnt $1 p$ cleavage always takes place at a consistent distance from the terminal tetraloop (Chanfreau et al., 2000). This suggests that Rnt $1 p$ effectively acts as a "helical ruler" that measures the distance from the tetraloop to the cleavage site (Chanfreau et al., 2000). Alternatively, the distance between the tetraloop and the cleavage site may not be measured but instead imposed by the enzyme structure that can only extend a certain distance once it binds to the terminal tetraloop. A tetraloop independent mechanism of substrate recognition must also exist because Rnt1p is capable of cleaving long duplex RNAs that lack the conserved tetraloop (Abou Elela et al., 1996). Additional experiments are required to decipher the mechanism of substrate recognition and to determine the ability of Rnt1p to select the tetraloop containing substrate when in competition with a long RNA duplex. Regardless of the exact mechanism, it is clear that Rnt1p selects the substrate in a different way than E. coli RNase III, which is influenced by antideterminant nucleotides near the cleavage site (Zhang and Nicholson, 1997).

\section{Rnt1p Mechanism of Action}

Rnt1p functions as a $108 \mathrm{kDa}$ homodimer (Lamontagne et al., 2000; Nagel and Ares, 2000) that forms through dimerization signals located at the $\mathrm{N}$-terminal domain and the dsRBD. Rnt1p cleaves RNA by binding to a cleavage site followed by hydrolysis and product release. RNA binding may take place in the absence of divalent metals and is largely insensitive to monovalent salt concentrations. RNA recognition and binding are performed by the 114 a.a. C-terminus that harbors the canonical dsRNA binding motif (Lamontagne et al., 2000; Nagel and Ares, 2000). To date, all RNA substrates found to bind Rnt1p could also be cleaved, suggesting that the dsRBD is the major determinant of RNA recognition (Chanfreau et al., 2000; Nagel and Ares, 2000). However, not all the Rnt1p/RNA complexes display the same cleavage efficiency. Also gelshift assays revealed that recombinant Rnt1p could form at least two protein/RNA complexes of differing molecular weight (Lamontagne et al., 2000). The larger complex readily cleaves its associated RNA upon the addition of $\mathrm{Mg}^{2+}$, while the smaller complex is less efficient and does not result in full RNA cleavage (Lamontagne et al., 2000). This suggests that the protein may bind RNA without cleaving, possibly due to miss-association or as a step towards an active RNA/protein complex.

Rnt1p requires $\mathrm{Mg}^{2+}$ for efficient RNA cleavage but may function with $\mathrm{Mn}^{2+}$. It is believed that Rnt1p like $E$. coli RNase III is a two metal-binding enzyme (Steitz and Steitz, 1993) because of the conserved stretches of acidic amino acids observed in its nuclease domain. However, the actual association of these conserved amino acid residues with divalent metal ions remains to be determined experimentally. In vitro, Rnt1p conducts two coordinated cleavage events and single cleavage is a rare event. In contrast, the product of a single cleavage event is more visible in vivo or in cell extracts (Chanfreau et al., 1997; Kufel et al., 2000; Kufel et al., 1999; Nagel and Ares, 2000). This difference may be a factor of the in vitro cleavage conditions or because elements that dissociate the enzyme after single cleavage exist in vivo. The kinetics of Rnt1p dependent RNA cleavage is similar to that of $E$. coli RNase III with a $\mathrm{K}_{\mathrm{m}}$ of $1.2 \mu \mathrm{M}$ and $\mathrm{k}_{\text {cat }}$ of $5.5 \mathrm{~min}^{-1}$ (Lamontagne et al., 2000). The chemical composition of the cleavage products and its affinity to Rnt $1 p$ have not been determined. Nevertheless, it is believed that Rnt1p functions similarly to both S. pombe Pac1 (Rotondo and Frendewey, 1996; Rotondo et al., 1997) and the E. colienzyme (Court, 1993; Nicholson, 1992; Nicholson et al., 1988) in leaving 3' hydroxyls and 5' phosphates. 


\section{Rnt1p Cellular Functions}

Similar to the E. coli RNase III, Rnt1p is not essential but its deletion in yeast causes sever growth defects and temperature sensitivity (Abou Elela and Ares, 1998). The most visible function of Rnt1p is on pre-rRNA processing (Abou Elela et al., 1996; Kufel et al., 1999). Inactivation of Rnt1p blocks the maturation of the 25S pre-rRNA 3' end and slows the formation of mature $5^{\prime}$ ends (Abou Elela et al., 1996; Kufel et al., 1999). In addition, Rnt1p initiates the 3 ' end processing of all Pol II transcribed small nuclear RNAs (snRNAs) including U1 (Seipelt et al., 1999), U2 (Abou Elela and Ares, 1998), U4 (Allmang et al., 1999), and U5 (Chanfreau et al., 1997). Deletion of RNT1 blocks $3^{\prime}$ end formation of U2 and the large form of U5 (U5L). In contrast, the steady-state levels of mature U1, U4, and U5 small form (U5S) are unchanged in $\triangle R N T 1$ cells because of an alternative processing pathway. Rnt $1 p$ also processes yeast polycistronic small nucleolar RNAs (snoRNAs) to separate them into individual RNAs (Chanfreau et al., 1998b; Chanfreau et al., 1998a; Kufel et al., 2000; Qu et al., 1999). Unlike the majority of snRNAs, snoRNAs processing is almost completely blocked in the absence of Rnt1p. As in the case with U2 snRNA, essential snoRNAs like U14 must remain partially functional without processing because RNT1 deletion is not lethal.

Rnt1p dependent processing of $25 \mathrm{~S}$ pre-rRNA, snRNAs, and snoRNAs seems to follow a general pathway that leads to mature RNA (see Figure 3). The first step is normally conducted by Rnt1p soon after RNA transcription followed by a helicase dependent unwinding of the cleaved helix, then trimming to the mature site by members of the exosome family (Kufel et al., 2000). In most cases, the mature site appears to be determined by an assembly protein (e.g. ribosomal protein) or a chaperon (e.g. yeast La protein) that binds and protects the mature site from further trimming by exonucleases (Allmang et al., 1999; Kufel et al., 2000; van Hoof et al., 2000; van Hoof et al., 2000).

A function of Rnt1p in the degradation or processing of mRNA similar to E. coli RNase III remains unconfirmed. However, the demonstrated effects of other eukaryotic RNase III orthologues like the fission yeast Pac1 and plant Caf on cell division and meiosis (lino et al., 1991; Jacobsen et al., 1999; Xu et al., 1990) suggest that roles other than the processing of stable untranslated RNAs also exist.

\section{Plant RNase III}

In plant, five potential RNase III orthologues were identified based on sequence homologies (See Figure 1) but only one (Caf) was identified experimentally (Jacobsen et al., 1999). The five orthologues originate from a single plant (Arabidopsis thaliana) and exhibits a $\mathrm{N}$-terminal domain, a nuclease domain, a helicase domain, and a dsRBD. All $A$. thaliana orthologues possess two nuclease domains and a single dsRBD with the exceptions of Tal3 that possesses 3 nuclease domains and Caf that possesses two dsRBDs (Jacobsen et al., 1999). The presence of multiple nuclease domains suggests the capacity of these enzymes to produce multiple cleavages with a single binding event.
This is in contrast to the bacterial and yeast RNase III which function as homodimers to introduce a coordinated double cleavage. The in vivo function and biochemical activities of plant RNase III remain unclear. However, the isolation of one A. thaliana RNase III (Caf) as a suppressor of a recessive mutation that causes unregulated cell division in floral meristems suggests a possible function in cell cycle or mitosis (Jacobsen et al., 1999).

\section{Metazoan RNase III}

In metazoan cells, both simple and helicase associated RNase III orthologues have been identified. In fly (Filippov et al., 2000), worm (Filippov et al., 2000), and human (Matsuda et al., 2000; Wu et al., 2000) all orthologues possess two nuclease domains like their plant counterpart. However, the human (hRNase III) and fly (drosha) simple version of RNase III appear to possess additional proline rich domain and serine/arginine rich domain of yet to be identified function (Filippov et al., 2000; Wu et al., 2000).

The two forms of human RNase III, hRNase III (Wu et al., 2000) and HERNA (Matsuda et al., 2000) have been cloned but only the enzymatic activity of hRNase III has been examined. The predicted protein sequence of hRNase III reveals a 1374 a.a. long protein that possesses five different domains. A C-terminal dsRBD followed by two nuclease domains, a proline rich domain, and an arginine/ serine rich domain. The $\mathrm{hRNase}$ III shares $37 \%$ of its amino acids sequence composition with the fly (drosha) and worm (Ce-drosha) RNase III (Filippov et al., 2000). The amino acid conservation extends well beyond the classical RNase III domain suggesting new conserved functions for the metazoan RNase III. In vitro, a recombinant GST fusion with the C-terminal domain of the human protein which includes both the dsRBD and the 2 nuclease domains cleaves dsRNA, but not ssRNA in presence of $\mathrm{Mg}^{2+}(\mathrm{Wu}$ et al., 2000). This suggests that the human RNase III cleavage activity is carried by the classical RNase III domains. It is not clear, if the human RNase III functions as dimer like its prokaryotic orthologues or if the inclusion of a second nuclease domain lift the need for dimerization. In vivo, antisense mediated depletion of hRNase III does not affect the level of nascent pre-rRNA transcript (45S) but results in a slight accumulation of the $32 \mathrm{~S}$ and $12 \mathrm{~S}$ rRNA precursor (Wu et al., 2000). This suggests a role in rRNA processing as shown for other RNase III orthologues. However, unlike yeast and E. coli RNase III, the human enzyme appears not to affect the early cleavage event of pre-rRNA processing. Thus, hRNase III may participate in pre-rRNA processing either indirectly or at a step other than that suggested for yeast and bacterial RNase III. In addition to its potential function in pre-rRNA processing, the hRNase III may serve different nuclear functions as implied by its cell cycle dependent shuttling between the nucleus and the nucleolus. Indeed, hRNase III may affect cell division like the plant and fission yeast orthologues (lino et al., 1991; Jacobsen et al., 1999; Xu et al., 1990). Antibodies against different peptides of hRNase III show that the protein is predominantly nucleolar in the $S$ phase of the cell cycle but exits to the nucleus in the G2/M phase (Wu et al., 2000). This is consistent with a role in pre-rRNA 
processing which is normally transcribed in the S phase. Finally, the universal distribution of the hRNase III in human tissues suggests a general function such as its role in prerRNA processing.

\section{Eukaryotic RNase III is a Potential Regulator of dsRNA Metabolism}

The discovery of eukaryotic RNase III will undoubtedly revolutionize the understanding of dsRNA metabolism in eukaryotic cells. Several intriguing dsRNAs related phenomena in eukaryotic cells await an explanation that can be easily provided by an RNase III-like enzyme. One facinating example is the phenomena of RNA interference (RNAi) or dsRNA mediated post-transcriptional gene silencing (PTGS). PTGS occurs when an RNA duplex corresponding to a sense and antisense sequences of endogeneous gene is introduced in the cell (Fagard and Vaucheret, 2000; Iyer et al., 2000; Marathe et al., 2000; Meins, 2000; Morel and Vaucheret, 2000; Sijen and Kooter, 2000; Wassenegger and Pelissier, 1998). Once in the cell, the RNA duplex appears to be converted into small RNA oligomers that range from 21 to 25 nucleotides in length (Caplen et al., 2000; Yang et al., 2000; Zamore et al., 2000). The newly generated RNA oligomers were proposed to interact with the target mRNA that displaces the sense strand of the duplex through an ATP-dependent helicase activity leading to mRNA degradation (Zamore et al., 2000). These PTGS associated activities strikingly fit the predicted profile of the human RNase III orthologues (Bass, 2000). The helicase associated RNase III are the only known enzymes that by themselves could convert long duplex RNA into short oligomers, then unwind the short oligonucleotides in an ATP-dependent manner.

RNase III orthologues are also predicted to participate in dsRNA mediated interferon response that combat viral infection and control the proliferation of malignant cells (Nicholson, 1996). In mammalian cells, dsRNA introduced ectopically or via viral infection binds to PKR (RNA dependent protein kinase) and triggers its autophosphorylation. Upon phosphorylation, PKR acquires a protein serine/therionine kinase activity that inhibits translation and initiates the interferon response (Clemens and Elia, 1997; Gale and Katze, 1998; Jaramillo et al., 1995; Robertson and Mathews, 1996; Samuel et al., 1997; Tan and Katze, 1999). Since PKR and RNase III share the conserved dsRNA binding motif, they are expected to compete for the same RNA. Consequently, the level of PKR induction may be determined by the outcome of a competition between dsRNA binding proteins essential for its activity and the processing properties of RNase III. For example, a viral dsRNA fragment may either interact with PKR to trigger interferon expression, or be cleaved by RNase III to suppress this immune response. On the other hand, RNase III may serve as active defense against viruses with dsRNA genomes. Indeed, over-expression of S. pombe RNase III in potato plants suppresses infection with the potato spindle tuber viroid (PSTVd) (Sano et al., 1997; Watanabe et al., 1995). Bacterial RNase III could be also used in a similar way to inhibit viral infection in tobacco plants (Langenberg et al., 1997). It is easy to imagine a similar approach to combat viral infection or suppress cellular immunity in mammalian cells.

\section{Acknowledgements}

Research in our laboratory is supported by grant \# MOP14305 from the Canadian Institute for Health Research (CIHR) and grant \# 216854 from the Natural Sciences and Engineering Research Council of Canada (NSERC). S. A. is a Chercheur-Boursier Junior II of the Fonds de la Recherche en Santé du Québec (FRSQ).

\section{References}

Abou Elela, S., and Ares, M., Jr. 1998. Depletion of yeast RNase III blocks correct U2 3 ' end formation and results in polyadenylated but functional U2 snRNA. EMBO J. 17: 3738-46.

Abou Elela, S., Igel, H., and Ares, M., Jr. 1996. RNase III cleaves eukaryotic preribosomal RNA at a U3 snoRNPdependent site. Cell. 85: 115-24.

Allmang, C., Kufel, J., Chanfreau, G., Mitchell, P., Petfalski, E., and Tollervey, D. 1999. Functions of the exosome in rRNA, snoRNA and snRNA synthesis. EMBO J.. 18: 5399410.

Bass, B. 2000. Double-stranded RNA as a template for gene silencing. Cell 101: 235-8.

Caplen, N. J., Fleenor, J., Fire, A., and Morgan, R. A. 2000. dsRNA-mediated gene silencing in cultured Drosophila cells: a tissue culture model for the analysis of RNA interference. Gene. 252: 95-105.

Chanfreau, G., Buckle, M., and Jacquier, A. 2000. Recognition of a conserved class of RNA tetraloops by Saccharomyces cerevisiae RNase III. Proc. Natl. Acad. Sci. USA. 97: 3142-7.

Chanfreau, G., Elela, S. A., Ares, M., Jr., and Guthrie, C. 1997. Alternative 3 '-end processing of U5 snRNA by RNase III. Genes Dev. 11: 2741-51.

Chanfreau, G., Legrain, P., and Jacquier, A. 1998b. Yeast RNase III as a key processing enzyme in small nucleolar RNAs metabolism. J. Mol. Biol. 284: 975-88.

Chanfreau, G., Rotondo, G., Legrain, P., and Jacquier, A. 1998a. Processing of a dicistronic small nucleolar RNA precursor by the RNA endonuclease Rnt1. EMBO J. 17: 3726-37.

Clemens, M. J., and Elia, A. 1997. The double-stranded RNA-dependent protein kinase PKR: structure and function. J. Interferon Cytokine Res. 17: 503-24.

Court, D. 1993. RNA processing and degradation by RNase III., J. G. a. B. Belasco, G., ed. New York: Academic Press. Fagard, M., and Vaucheret, H. 2000. Systemic silencing signals. Plant Mol. Biol. 43: 285-93.

Filippov, V., Solovyev, V., Filippova, M., and Gill, S. S. 2000. A novel type of RNase III family proteins in eukaryotes. Gene 245: 213-21.

Gale, M., Jr., and Katze, M. G. 1998. Molecular mechanisms of interferon resistance mediated by viraldirected inhibition of PKR, the interferon-induced protein kinase. Pharmacol. Ther. 78: 29-46.

lino, Y., Sugimoto, A., and Yamamoto, M. 1991. S. pombe pac1+, whose overexpression inhibits sexual 
development, encodes a ribonuclease III-like RNase. EMBO J. 10: 221-6.

lyer, L. M., Kumpatla, S. P., Chandrasekharan, M. B., and Hall, T. C. 2000. Transgene silencing in monocots. Plant Mol. Biol. 43: 323-46.

Jacobsen, S. E., Running, M. P., and Meyerowitz, E. M. 1999. Disruption of an RNA helicase/RNAse III gene in Arabidopsis causes unregulated cell division in floral meristems. Development. 126: 5231-43.

Jaramillo, M. L., Abraham, N., and Bell, J. C. 1995. The interferon system: a review with emphasis on the role of PKR in growth control. Cancer Invest. 13: 327-38.

Kharrat, A., Macias, M. J., Gibson, T. J., Nilges, M., and Pastore, A. 1995. Structure of the dsRNA binding domain of E. coli RNase III. EMBO J. 14: 3572-84.

Kufel, J., Allmang, C., Chanfreau, G., Petfalski, E., Lafontaine, D. L., and Tollervey, D. 2000. Precursors to the U3 small nucleolar RNA lack small nucleolar RNP proteins but are stabilized by La binding. Mol. Cell Biol. 20: 5415-24.

Kufel, J., Dichtl, B., and Tollervey, D. 1999. Yeast Rnt1p is required for cleavage of the pre-ribosomal RNA in the $3^{\prime}$ ETS but not the 5' ETS. RNA. 5: 909-17.

Lamontagne, B., Tremblay, A., and Abou Elela, S. 2000. The N-terminal domain that distinguishes yeast from bacterial RNase III contains a dimerization signal required for efficient double-stranded RNA cleavage. Mol. Cell Biol. 20: 1104-15.

Langenberg, W. G., Zhang, L., Court, D., Giunchedi, L., and Mirtra, A. 1997. Transgenic tobacco plants expressing the bacterial rnc gene resist virus infection. Molecular Breeding. 3: 391-399.

Lykke-Andersen, J., Aagaard, C., Semionenkov, M., and Garrett, R. A. 1997. Archaeal introns: splicing, intercellular mobility and evolution. Trends Biochem Sci 22: 326-31.

Marathe, R., Anandalakshmi, R., Smith, T. H., Pruss, G. J., and Vance, V. B. 2000. RNA viruses as inducers, suppressors and targets of post- transcriptional gene silencing. Plant Mol. Biol. 43: 295-306.

Matsuda, S., Ichigotani, Y., Okuda, T., Irimura, T., Nakatsugawa, S., and Hamaguchi, M. 2000. Molecular cloning and characterization of a novel human gene HERNA which encodes a putative RNA-helicase. Biochim. Biophys. Acta. 1490: 163-9.

Meins, F., Jr. 2000. RNA degradation and models for posttranscriptional gene-silencing. Plant Mol. Biol. 43: 26173.

Mian, I. S. 1997. Comparative sequence analysis of ribonucleases HII, III, II PH and D. Nucleic Acids Res. 25: 3187-95.

Morel, J. B., and Vaucheret, H. 2000. Post-transcriptional gene silencing mutants. Plant Mol. Biol. 43: 275-84.

Nagel, R., and Ares, M., Jr. 2000. Substrate recognition by a eukaryotic RNase III: the double-stranded RNA-binding domain of Rnt1p selectively binds RNA containing a 5'AGNN-3' tetraloop. RNA. 6: 1142-56.

Nicholson, A. W. 1992. Accurate enzymatic cleavage in vitro of a 2'-deoxyribose-substituted ribonuclease III processing signal. Biochim. Biophys. Acta. 1129: 318-22. Nicholson, A. W. 1999. Function, mechanism and regulation of bacterial ribonucleases. FEMS Microbiol. Rev. 23: 371-
90.

Nicholson, A. W. 1996. Structure, reactivity, and biology of double-stranded RNA. Prog. Nucleic Acid Res. Mol. Biol. 52: 1-65.

Nicholson, A. W., Niebling, K. R., McOsker, P. L., and Robertson, H. D. 1988. Accurate in vitro cleavage by RNase III of phosphorothioate-substituted RNA processing signals in bacteriophage T7 early mRNA. Nucleic Acids Res. 16: 1577-91.

Ozier-Kalogeropoulos, O., Malpertuy, A., Boyer, J., Tekaia, F., and Dujon, B. 1998. Random exploration of the Kluyveromyces lactis genome and comparison with that of Saccharomyces cerevisiae. Nucleic Acids Res. 26: 5511-24.

Qu, L. H., Henras, A., Lu, Y. J., Zhou, H., Zhou, W. X., Zhu, Y. Q., Zhao, J., Henry, Y., Caizergues-Ferrer, M., and Bachellerie, J. P. 1999. Seven novel methylation guide small nucleolar RNAs are processed from a common polycistronic transcript by Rat1p and RNase III in yeast. Mol. Cell Biol. 19: 1144-58.

Robertson, H. D., and Mathews, M. B. 1996. The regulation of the protein kinase PKR by RNA. Biochimie. 78: 90914.

Rotondo, G., and Frendewey, D. 1996. Purification and characterization of the Pac1 ribonuclease of Schizosaccharomyces pombe. Nucleic Acids Res. 24: 2377-86.

Rotondo, G., Gillespie, M., and Frendewey, D. 1995. Rescue of the fission yeast snRNA synthesis mutant snm1 by overexpression of the double-strand-specific Pac1 ribonuclease. Mol. Gen. Genet. 247: 698-708.

Rotondo, G., Huang, J. Y., and Frendewey, D. 1997. Substrate structure requirements of the Pac1 ribonuclease from Schizosaccharmyces pombe. RNA. 3: 1182-93.

Samuel, C. E., Kuhen, K. L., George, C. X., Ortega, L. G., Rende-Fournier, R., and Tanaka, H. 1997. The PKR protein kinase: an interferon-inducible regulator of cell growth and differentiation. Int. J. Hematol. 65: 227-37.

Sano, T., Nagayama, A., Ogawa, T., Ishida, I., and Okada, Y. 1997. Transgenic potato expressing a double-stranded RNA-specific ribonuclease is resistant to potato spindle tuber viroid. Nat. Biotechnol. 15: 1290-4.

Seipelt, R. L., Zheng, B., Asuru, A., and Rymond, B. C. 1999. U1 snRNA is cleaved by RNase III and processed through an Sm site- dependent pathway. Nucleic Acids Res. 27: 587-95.

Sijen, T., and Kooter, J. M. 2000. Post-transcriptional genesilencing: RNAs on the attack or on the defense? Bioessays. 22: 520-31.

St Johnston, D., Brown, N. H., Gall, J. G., and Jantsch, M. 1992. A conserved double-stranded RNA-binding domain. Proc. Natl. Acad. Sci. USA. 89, 10979-83.

Steitz, T. A., and Steitz, J. A. 1993. A general two-metalion mechanism for catalytic RNA. Proc. Natl. Acad. Sci. USA. 90: 6498-502.

Tan, S. L., and Katze, M. G. 1999. The emerging role of the interferon-induced PKR protein kinase as an apoptotic effector: a new face of death? J. Interferon Cytokine Res. 19: 543-54.

van Hoof, A., Lennertz, P., and Parker, R. 2000a. Three 
conserved members of the RNase $D$ family have unique and overlapping functions in the processing of $5 S, 5.8 S$, U4, U5, RNase MRP and RNase P RNAs in yeast. EMBO J. 19: 1357-65.

van Hoof, A., Lennertz, P., and Parker, R. 2000b. Yeast exosome mutants accumulate 3 '-extended polyadenylated forms of $U 4$ small nuclear RNA and small nucleolar RNAs. Mol. Cell Biol. 20: 441-52.

Wassenegger, M., and Pelissier, T. 1998. A model for RNAmediated gene silencing in higher plants. Plant Mol. Biol. 37: 349-62.

Watanabe, Y., Ogawa, T., Takahashi, H., Ishida, I., Takeuchi, Y., Yamamoto, M., and Okada, Y. 1995. Resistance against multiple plant viruses in plants mediated by a double stranded-RNA specific ribonuclease. FEBS Lett. 372: 165-8.

Wu, H., Xu, H., Miraglia, L. J., and Crooke, S. T. 2000. Human RNase III is a $160-\mathrm{kDa}$ protein involved in preribosomal RNA processing [In Process Citation]. J. Biol. Chem. 275: 36957-65.

Xu, H. P., Riggs, M., Rodgers, L., and Wigler, M. 1990. A gene from $S$. pombe with homology to $E$. coli RNAse III blocks conjugation and sporulation when overexpressed in wild type cells. Nucleic Acids Res. 18: 5304.

Yang, D., Lu, H., and Erickson, J. W. 2000. Evidence that processed small dsRNAs may mediate sequence-specific mRNA degradation during RNAi in drosophila embryos [In Process Citation]. Curr. Biol. 10: 1191-200.

Zamore, P. D., Tuschl, T., Sharp, P. A., and Bartel, D. P. 2000. RNAi: double-stranded RNA directs the ATPdependent cleavage of mRNA at 21 to 23 nucleotide intervals. Cell. 101: 25-33.

Zhang, K., and Nicholson, A. W. 1997. Regulation of ribonuclease III processing by double-helical sequence antideterminants. Proc. Natl. Acad. Sci. USA. 94: 1343741.

Zhou, D., Frendewey, D., and Lobo Ruppert, S. M. 1999. Pac1p, an RNase III homolog, is required for formation of the $3^{\prime}$ end of U2 snRNA in Schizosaccharomyces pombe. RNA. 5: 1083-98. 


\section{Further Reading}

Caister Academic Press is a leading academic publisher of advanced texts in microbiology, molecular biology and medical research. Full details of all our publications at caister.com

- MALDI-TOF Mass Spectrometry in Microbiology Edited by: M Kostrzewa, S Schubert (2016) www.caister.com/malditof

- Aspergillus and Penicillium in the Post-genomic Era Edited by: RP Vries, IB Gelber, MR Andersen (2016) www.caister.com/aspergillus2

- The Bacteriocins: Current Knowledge and Future Prospects Edited by: RL Dorit, SM Roy, MA Riley (2016)

www.caister.com/bacteriocins

- Omics in Plant Disease Resistance Edited by: V Bhadauria (2016) www.caister.com/opd

- Acidophiles: Life in Extremely Acidic Environments Edited by: R Quatrini, DB Johnson (2016) www.caister.com/acidophiles

- Climate Change and Microbial Ecology: Current Research and Future Trend

Edited by: J Marxsen (2016)

www.caister.com/climate

- Biofilms in Bioremediation: Current Research and Emerging Technologies

Edited by: G Lear (2016)

www.caister.com/biorem

- Microalgae: Current Research and Applications Edited by: MN Tsaloglou (2016) www.caister.com/microalgae

- Gas Plasma Sterilization in Microbiology: Theory, Applications, Pitfalls and New Perspectives Edited by: H Shintani, A Sakudo (2016) www.caister.com/gasplasma

- Virus Evolution: Current Research and Future Directions Edited by: SC Weaver, M Denison, M Roossinck, et al. (2016) www.caister.com/virusevol

- Arboviruses: Molecular Biology, Evolution and Control Edited by: N Vasilakis, DJ Gubler (2016) www.caister.com/arbo

- Shigella: Molecular and Cellular Biology Edited by: WD Picking, WL Picking (2016) www.caister.com/shigella

-Aquatic Biofilms: Ecology, Water Quality and Wastewater Treatment

Edited by: AM Romaní, H Guasch, MD Balaguer (2016)

www.caister.com/aquaticbiofilms

- Alphaviruses: Current Biology

Edited by: S Mahalingam, L Herrero, B Herring (2016)

www.caister.com/alpha

- Thermophilic Microorganisms

Edited by: F Li (2015)

www.caister.com/thermophile
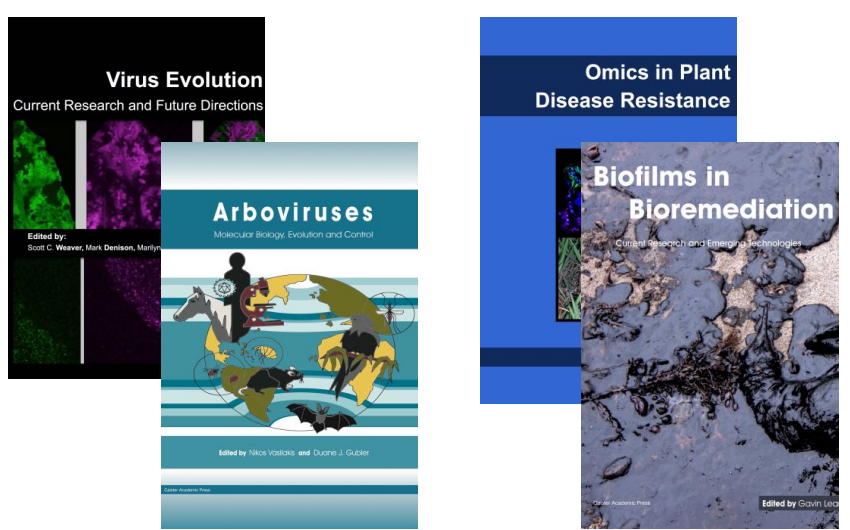
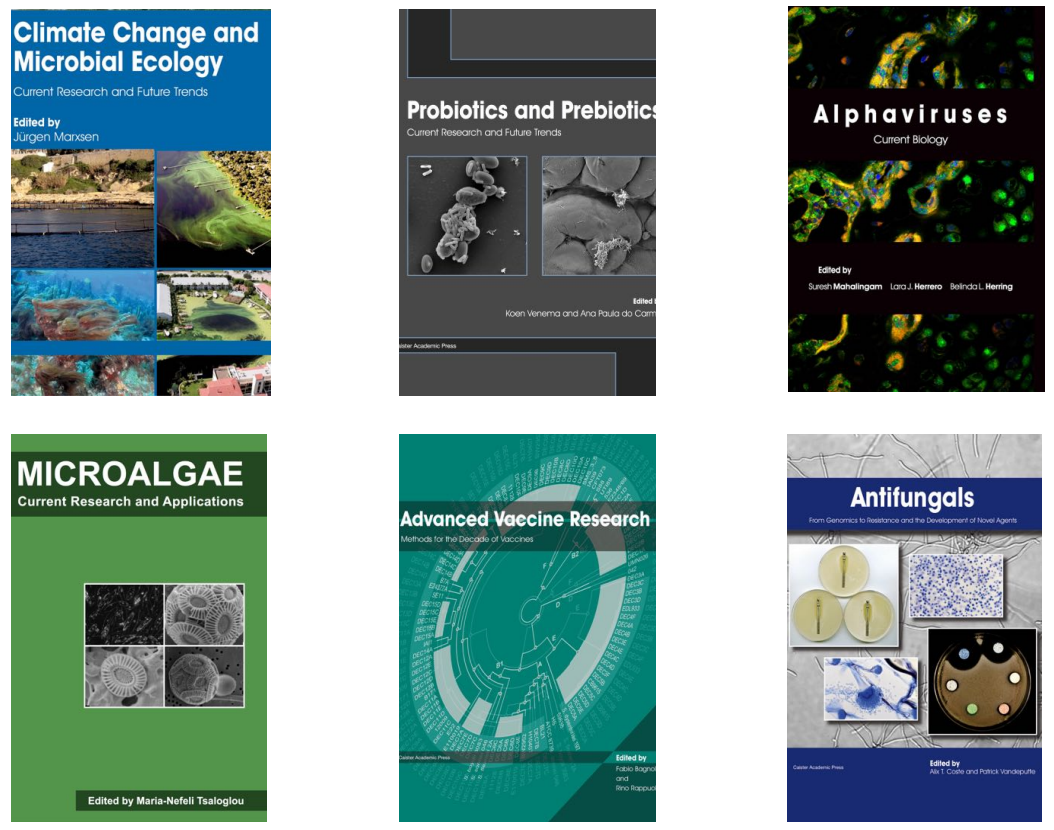

- Flow Cytometry in Microbiology: Technology and Applications Edited by: MG Wilkinson (2015) www.caister.com/flow

- Probiotics and Prebiotics: Current Research and Future Trends Edited by: K Venema, AP Carmo (2015) www.caister.com/probiotics

- Epigenetics: Current Research and Emerging Trends Edited by: BP Chadwick (2015) www.caister.com/epigenetics2015

- Corynebacterium glutamicum: From Systems Biology to Biotechnological Applications

Edited by: A Burkovski (2015)

www.caister.com/cory2

- Advanced Vaccine Research Methods for the Decade of Vaccines

Edited by: F Bagnoli, R Rappuoli (2015)

www.caister.com/vaccines

- Antifungals: From Genomics to Resistance and the Development of Novel Agents

Edited by: AT Coste, P Vandeputte (2015)

www.caister.com/antifungals

- Bacteria-Plant Interactions: Advanced Research and Future Trends Edited by: J Murillo, BA Vinatzer, RW Jackson, et al. (2015) www.caister.com/bacteria-plant

\section{- Aeromonas}

Edited by: J Graf (2015)

www.caister.com/aeromonas

- Antibiotics: Current Innovations and Future Trends

Edited by: S Sánchez, AL Demain (2015)

www.caister.com/antibiotics

- Leishmania: Current Biology and Contro Edited by: S Adak, R Datta (2015) www.caister.com/leish2

- Acanthamoeba: Biology and Pathogenesis (2nd edition) Author: NA Khan (2015)

www.caister.com/acanthamoeba2

- Microarrays: Current Technology, Innovations and Applications Edited by: Z He (2014)

www.caister.com/microarrays2

- Metagenomics of the Microbial Nitrogen Cycle: Theory, Methods and Applications

Edited by: D Marco (2014)

www.caister.com/n2 